\title{
Structural Alterations of Paraná's Oxisols by Cover Crops
}

\author{
Maurício Antônio Pilatti ${ }^{1}$, Deonir Secco ${ }^{1}$, Luiz Antônio Zanão Jr. ${ }^{1}$, Araceli Ciotti de Marins ${ }^{1}$, \\ Luciene Kazue Tokura ${ }^{1} \&$ Bruna de Villa ${ }^{1}$ \\ ${ }^{1}$ Western Paraná State University, Cascavel, Paraná, Brazil \\ Correspondence: Maurício Antônio Pilatti, Western Paraná State University, Cascavel, Paraná, Brazil. Tel: \\ 55-(45)-3220-3151. E-mail: mpilatti@hotmail.com
}

Received: May 7, 2018

doi:10.5539/jas.v10n9p180
Accepted: June 15, 2018 Online Published: August 15, 2018

URL: https://doi.org/10.5539/jas.v10n9p180

\begin{abstract}
This work aimed to evaluate the dynamics of physical and hydric attributes of a clayey Latosol cultivated with different cover species. The experimental area was located in the Agronomic Institute of Paraná (IAPAR), in the regional hub of Santa Tereza do Oeste, Paraná, Brazil. The experiment was comprised of seven cover species also called treatments is the course of this work. Three of them were isolated summer species notably Crotalaria juncea, Crotalaria spectabilis, Cajanus cajan (pigeon pea), and the other four treatments winter species cultivated individually or in association including Avena strigosa (Black oat), + (Avena stirgosa + Raphamus sativus (radish), Avena strigosa + Lupinus albus (Lupin bean), and (Avena strigosa + Pisum sativum (pea). The treatments were distributed on a completely random plots of $20 \mathrm{~m} \times 25 \mathrm{~m}$ without replication. Soil density, macroporosity, and saturated hydraulic conductivity were measured to follow the changes of the soil structure. Statistical analyses showed that cover crops species did not lead to a significant improvement in soil structural status. Soil density varied between 1.08 and $1.12 \mathrm{Mg} \mathrm{m}^{-3}$, macroporosity from 15.22 and $16.90 \%$, and saturated hydraulic conductivity ranged from 28.83 to $45.07 \mathrm{~mm} \mathrm{~h}^{-1}$. Soybean grain yield were considered satisfactory in $2016\left(\right.$ mean $\left.=1909.68 \mathrm{~kg} \mathrm{ha}^{-1}\right)$ and in $2017\left(\right.$ mean $\left.=3355.30 \mathrm{~kg} \mathrm{ha}^{-1}\right)$ most probably due to the good initial structural conditions of the soil, alongside with the good climatic conditions during the two campaigns. Furthermore, the soybean grain yield was positively influenced by Ds which ranged from 1.0 to $1.17 \mathrm{Mg} \mathrm{m}^{-3}$.
\end{abstract}

Keywords: physical-hydric attributes, summer species, winter species, soybean grain yield, Brazil

\section{Introduction}

The soil is one of the most important resources on our planet, and its conservation has been an aspect of great relevance for a more sustainable production. The availability of water is one of the main physical factors that have a direct influence on the development and production of agricultural crops (Reichert et al., 2011; Serafim et al., 2013).

Soil structure is an important property of the soil, as it affects the retention and transportation rates of water, gases and nutrients in the soil (Zhao et al., 2016). Among the most widely used properties to evaluate soil structure, water infiltration is one of the most important, as it integrates different factors, such as size distribution and pore continuity, soil density, macroporosity and saturated hydraulic conductivity (Santos \& Pereira, 2013).

The aim of sustainable development is to combine production with conservation of natural resources such as water and soil, through adoption of conservationist practices, among which the cultivation cover crops (Stone \& Silveira, 2001) is particularly noteworthy cover crops play a key role in the recovery or maintenance of the soil physical qualities, providing positive effects such as suppression of spontaneous plants thus limiting the demand for water, soil moisture conservation, nutrient cycling, and erosion control (Doneda, 2010).

The knowledge and understanding of the effects of certain cover crops on a possible improvement of soil physical properties, such as porosity and density, is of great importance in the search for the sustainability of agriculture. The purpose of this work was to evaluate the changes in the physical and hydric attributes of oxisols in Paraná resulting from cultivations of different cover crops, and the effects of these changes on soybean grain yields. 


\section{Material and Methods}

\subsection{Location and Description of the Study Area}

The experiment was carried out at the Experimental Station of the Agronomic Institute of Paraná (IAPAR), in the regional pole of Santa Tereza do Oeste, Paraná, Brazil.

The local relief is mildly undulating, with a mean slope of $30 \%$ in the southwest-northeast direction and $8 \%$ in the southeast-northeast direction in relation to the geographic north. The soil of the experimental area is classified as typical dystroferric red Latosol (Embrapa, 2013). The region is located between $53^{\circ} 29^{\prime} 37^{\prime \prime} \mathrm{W}$ longitude and $24^{\circ} 50^{\prime} 42^{\prime \prime} \mathrm{S}$ longitude, and $750 \mathrm{~m}$ in altitude. The climate of the region according to the Köppen classification is mesothermal subtropical wet, with average annual rainfall of $1840 \mathrm{~mm}$ and relative humidity of $75-80 \%$ (IAPAR, 2000).

\subsection{Experimental Design and Description of Treatments}

The experimental design was completely randomized plots of $20 \mathrm{~m}$ in width by $25 \mathrm{~m}$ in length each, totaling seven plots without replication.

The soil was not tilled and the 7 soil covering species used consisted of three summer species in isolation viz: Crotalaria juncea (Crotalaria juncea), Crotalaria spectabilis (Crotalaria spectabilis), pigeon pea (Cajanus cajan), and four winter species cultivated individually or in association including (i) Black oat (Avena strigosa), (ii) Black oat + radish (Avena stirgosa + Raphamus sativus), (iii) Black oat + Lupin bean (Avena strigosa + Lupinus albus), and (iv) Black oat + pea (Avena strigosa + Pisum sativum).

\subsection{Implantation and Crop Treatment of the Cover Species and Soybean Crop}

In March 2015, the sowing of three cover species of the summer cycle namely Crotalaria juncea, Crotalaria spectabilis, and Cajanus cajan (pigeon pea) was carried out, followed by the sowing of the winter cover species in May 2015. The sowing of the covers was performed without any basic chemical fertilization. All species were managed with triton in full bloom.

The soybean cultivar Vmax RR-NK7059 was planted in November 2015 and 2016 (two cropping campaigns), spaced $0.45 \mathrm{~m}$ between rows and 16 seeds per linear meter within rows. The soybean management and crop treatments followed the recommendations for the crop, requiring the application of herbicides to control weeds, insecticides for pest control and fungicides to control diseases, mainly of Phakopsora pachyrhizi.

\subsection{Climatological Assessments}

Data on rainfall, temperature and monthly crop evapotranspiration that control soybean development were collected from with field pluviometer at the IAPAR experimental station. For the calculation of the soybean evapotranspiration, Thornthwaite method adapted by Camargo et al. (1999) based on the effective temperature was used.

\subsection{Analytical Assessments and Determinations}

Undisturbed samples were collected in three layers: $0-0.1 ; 0.1-0.2$; and $0.2-0.3 \mathrm{~m}$, always considering the intermediate depth of the target layer, using cylinders with $0.05 \mathrm{~m}$ in height and $0.05 \mathrm{~m}$ in diameter. They were collected in triplicates at each depth in order to obtain representative samples, considering the major dispersion of the physical attributes and preventing loss of samples during the execution of the laboratory procedures.

Soil physical parameters determined were the density, macroporosity and saturated hydraulic conductivity. For soil density and macroporosity, a sand column was used to allow the selective extraction of water at the pre-established voltages (Reinert \& Reichert, 2006). Subsequently, the samples were weighed and saturated again for 24 hours for the determination of the saturated hydraulic conductivity under constant load permeameter The calculations for the hydraulic conductivity of the soil were performed according to the methodology recommended by Embrapa (1997).

\subsection{Statistical Analysis}

Soil physical-hydric attributes and soybean were submitted to an analysis of variance. A comparison of mean values of the above soil physical-hydric parameters was carried out using Tukey's test at $5 \%$ probability by the program Sisvar, version 5.6 (Ferreira et al., 2011). Correlation between soybean yields and soil physical-hydric properties were analyzed using the electronic spreadsheet of Microsoft Excel, version 16.0-Office 2016. Multiple linear regression models and graphs were built using the program R (R Core Team, 2016). 


\section{Results and Discussion}

\subsection{Soybean Development as a Function of Climatic Factors}

Requirement in terms of rainfall, temperature and monthly crop evapotranspiration varied with the vegetative and reproductive stages of the soybean during the two cropping campaigns (October 2015 and February 2016, and October 2016 and February 2017) are shown in Figure 1.

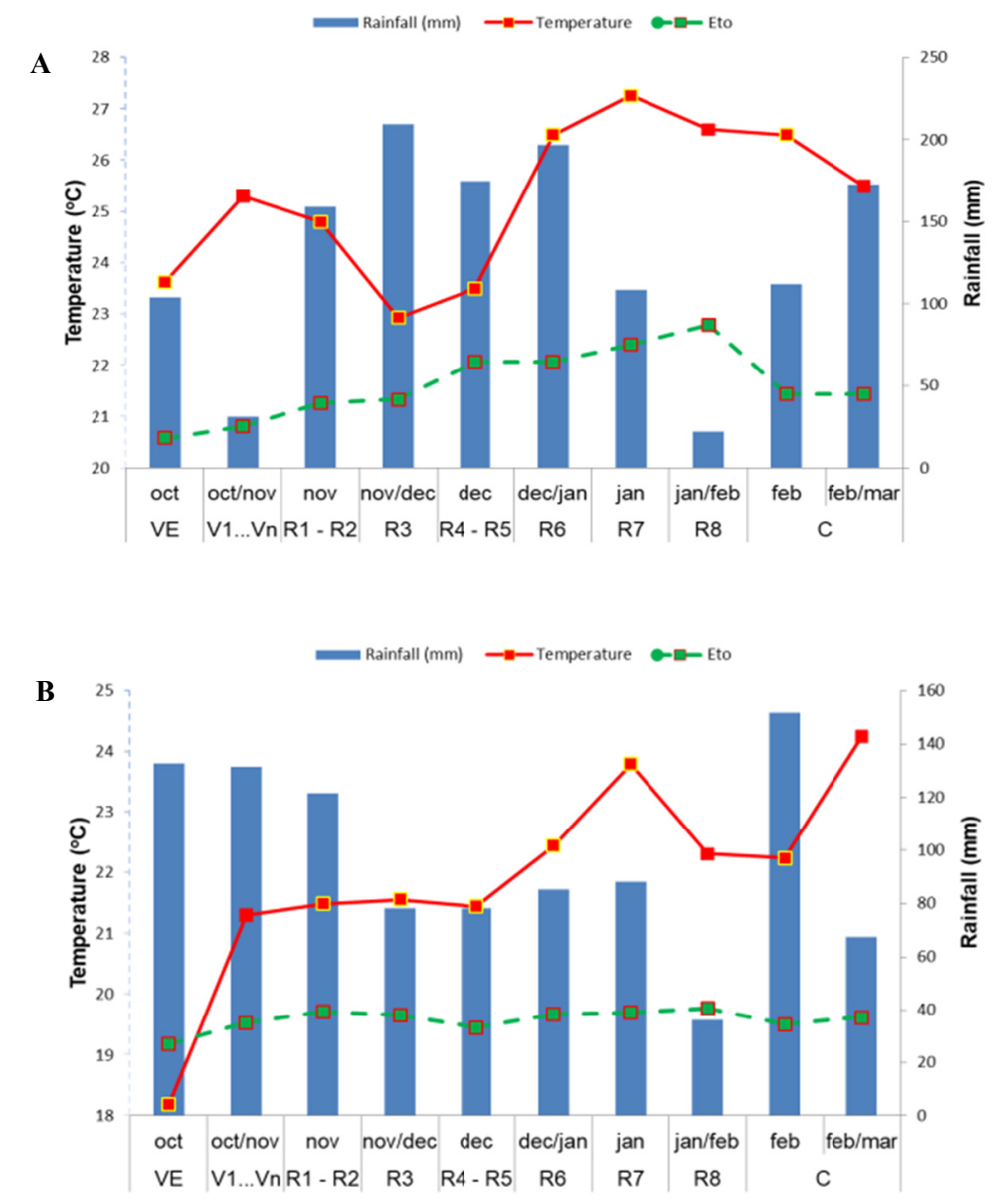

Figure 1. Rainfall, mean temperature and evapotranspiration (ETo) of the soybean crop from October to February 2016 (A) and 2017 (B)

\subsection{Soil Physical-hydric Attributes}

Figure 2 (A and C) showed the Ds data for the cover species, for the 0-0.10 m layer (A) and 0.20-0.30 m layer (C), presented discrepant points around the means and their distribution. In the $0-0.10 \mathrm{~m}$ layer (A), the species black oat + lupin bean presented a variability. In the 0.20-0.30 layer (C), the species Crotalaria juncea presented great variability, which was illustrated by the sizes of the boxes and bars and the discrepant points. 


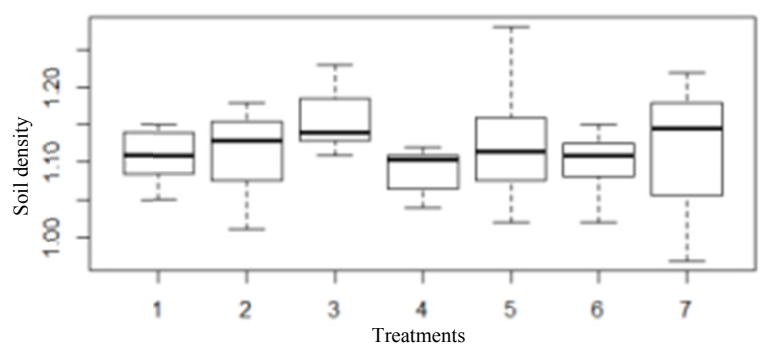

A

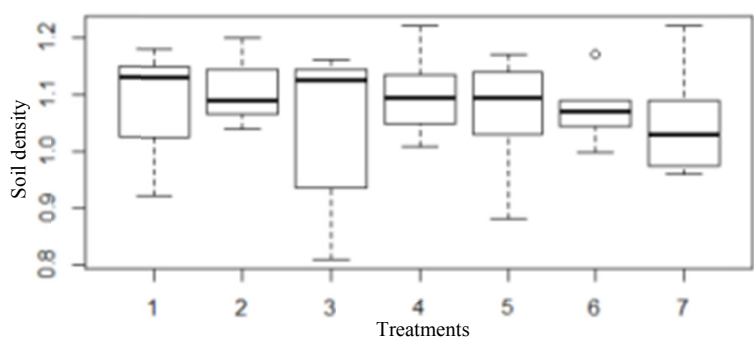

B

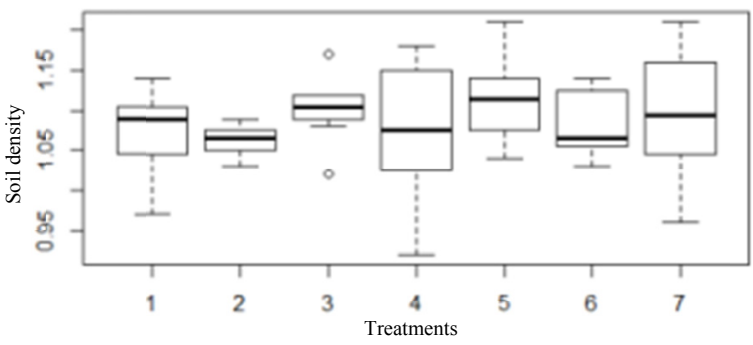

C

Figure 2. Ds boxplot of 0-0.10 m layer (A), 0.10-0.20 m layer (B), and 0.20-0.30 m layer (C) for different cover species. 1 (black oat), 2 (black oat + radish), 3 (Crotalaria juncea), 4 (pigeon pea), 5 (Crotalaria spectabilis), 6

(black oat + lupin bean), 7 (black oat + pea)

Results of the macroporosity showed a discrepancy for the 0.10-0.20 m layer (B) exhibited by Crotalaria juncea (Figure 3), that might have influenced the saturated hydraulic conductivity, as demonstrated hereafter in Figure 4.

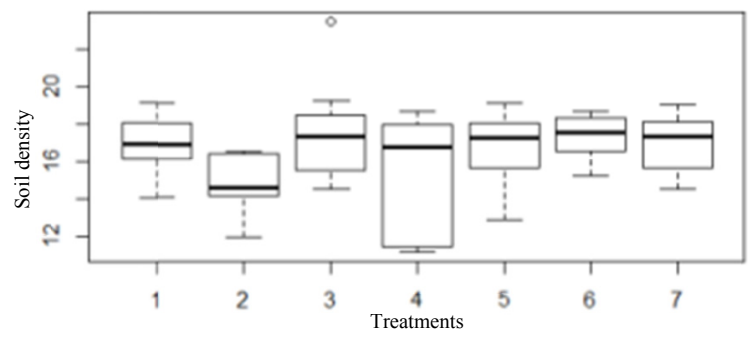

A

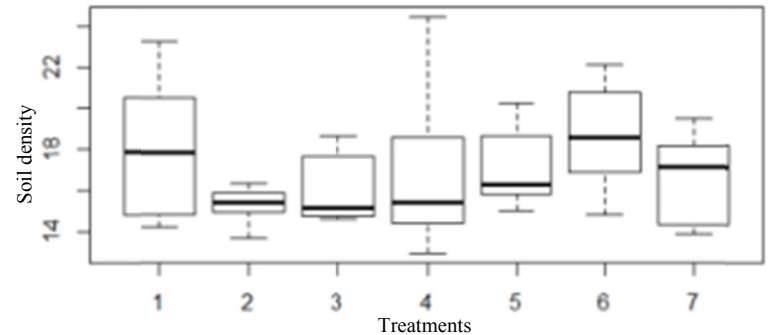

B

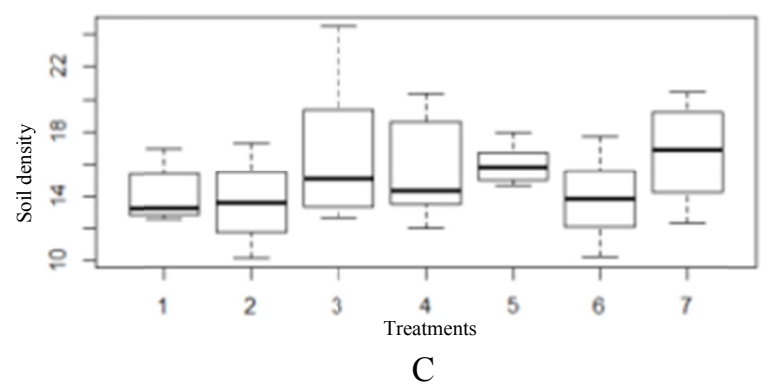

Figure 3. Macro boxplot of 0-0.10 m layer (A), 0.10-0.20 m layer (B), and 0.20-0.30 m layer (C) for cover species. 1 (black oat), 2 (black oat + radish), 3 (Crotalaria juncea), 4 (pigeon pea), 5 (Crotalaria spectabilis), 6

(black oat + lupin bean), 7 (black oat + pea)

Discrepant points were observed regarding the saturated hydraulic concentration (Figure 4), as well as a concentration of values close to the lowest obtained, since the rectangle, limited by the upper and lower quartiles, was closer to the minimum value, showing asymmetry. In the 0.10-0.20 m layer (B) and 0.20-0.30 m layer (C), 
the species that presented the most discrepant points were black oat + radish; pigeon pea; Crotalaria juncea, and black oat + pea.

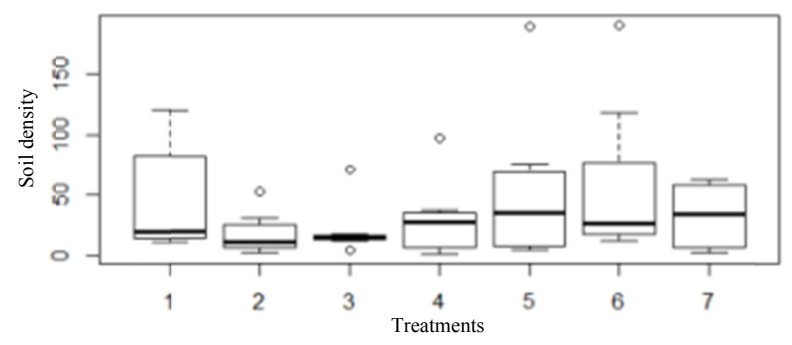

A

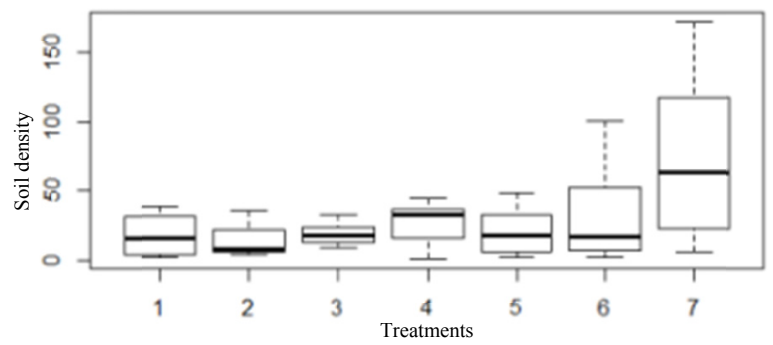

$\mathrm{B}$

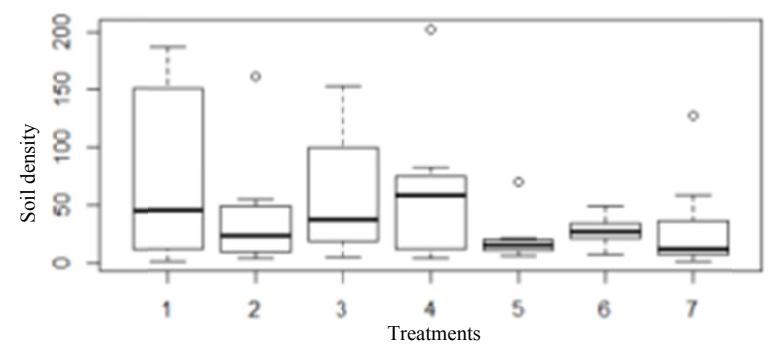

$\mathrm{C}$

Figure 4. Ksat boxplot of 0-0.10 m layer (A), 0.10-0.20 m layer (B), and 0.20-0.30 m layer (C) for cover species. 1 (black oat), 2 (black oat + radish), 3 (Crotalaria juncea), 4 (pigeon pea), 5 (Crotalaria spectabilis), 6 (black oat + lupin bean), 7 (black oat + pea)

The analysis of variance for Ds, Macro and Ksat for the different species of cover crops for the period 2016-2017 in the three layers are presented in Table 1. 
Table 1. Mean values of soil density (Ds), macroporosity (Macro) and saturated hydraulic conductivity (Ksat) in the three layers as a function of different soil cover species

\begin{tabular}{|c|c|c|c|c|c|c|}
\hline \multirow{2}{*}{ Cover species } & \multicolumn{2}{|c|}{ Ds $\left(\mathrm{Mg} \mathrm{m}^{-3}\right)$} & \multicolumn{2}{|c|}{ Macro (\%) } & \multicolumn{2}{|c|}{ Ksat $\left(\mathrm{mm} \mathrm{h}^{-1}\right)$} \\
\hline & 2016 & 2017 & 2016 & 2017 & 2016 & 2017 \\
\hline \multicolumn{7}{|l|}{$0.0-0.10 \mathrm{~m}$ layer } \\
\hline Black oat & 1.14 & 1.04 & $14.87 \mathrm{~A}$ & $13.33 \mathrm{Ba}$ & $17.80 \mathrm{~b}$ & 17.76 \\
\hline Black oat + radish & 1.12 & 1.00 & $13.91 \mathrm{~B}$ & $19.31 \mathrm{Aa}$ & $22.12 \mathrm{ab}$ & 15.61 \\
\hline Black oat + lupin bean & 1.09 & 1.11 & $17.79 \mathrm{~A}$ & 13.54 Bab & $27.93 \mathrm{ab}$ & 25.86 \\
\hline Black oat + pea & 1.14 & 1.07 & $13.87 \mathrm{~A}$ & $13.44 \mathrm{Aab}$ & $10.82 \mathrm{~b}$ & 16.02 \\
\hline Crotalaria juncea & 1.10 & 1.04 & $15.82 \mathrm{~A}$ & 16.13 Aab & $31.16 \mathrm{ab}$ & 9.10 \\
\hline Pigeon pea & 1.00 & 1.09 & $18.03 \mathrm{~A}$ & 15.31 Aab & $90.31 \mathrm{a}$ & 55.68 \\
\hline Crotalaria spectabilis & 1.06 & 1.09 & $14.71 \mathrm{~A}$ & $13.06 \mathrm{Ab}$ & $18.19 \mathrm{ab}$ & 45.30 \\
\hline Mean & 1.08 & & 15.22 & & 28.83 & \\
\hline Column DMS & 0.18 & & 5.96 & & 72.26 & \\
\hline Row DMS & 0.12 & & 3.90 & & 47.23 & \\
\hline CV $(\%)$ & 7.85 & & 18.03 & & 115.29 & \\
\hline $\mathrm{Fc}$ & 1.90 & & 2.50 & & 0.71 & \\
\hline $\operatorname{Pr}>\mathrm{Fc}$ & 0.09 & & 0.03 & & 0.64 & \\
\hline \multicolumn{7}{|l|}{$0.10-0.20 \mathrm{~m}$ layer } \\
\hline Black oat & $1.11 \mathrm{~A}$ & $1.10 \mathrm{~A}$ & 15.98 & 17.82 & $15.72 \mathrm{~B}$ & $75.06 \mathrm{~A}$ \\
\hline Black oat + radish & $1.14 \mathrm{~A}$ & $1.17 \mathrm{~A}$ & 16.82 & 18.29 & $27.39 \mathrm{~A}$ & $13.93 \mathrm{~A}$ \\
\hline Black oat + lupin bean & $1.08 \mathrm{~A}$ & $1.10 \mathrm{~A}$ & 15.46 & 15.07 & $20.06 \mathrm{~A}$ & $39.69 \mathrm{~A}$ \\
\hline Black oat + pea & $1.13 \mathrm{~A}$ & $1.09 \mathrm{~A}$ & 14.95 & 14.67 & $7.05 \mathrm{~A}$ & $28.45 \mathrm{~A}$ \\
\hline Crotalaria juncea & $1.07 \mathrm{~B}$ & $1.17 \mathrm{~A}$ & 15.50 & 17.98 & $38.73 \mathrm{~A}$ & $65.94 \mathrm{~A}$ \\
\hline Pigeon pea & $1.07 \mathrm{~B}$ & $1.16 \mathrm{~A}$ & 16.53 & 17.38 & $35.72 \mathrm{~A}$ & $29.96 \mathrm{~A}$ \\
\hline Crotalaria spectabilis & $1.07 \mathrm{~A}$ & $1.13 \mathrm{~A}$ & 16.76 & 17.92 & $21.34 \mathrm{~B}$ & $89.51 \mathrm{~A}$ \\
\hline Mean & 1.11 & & 16.51 & & 36.32 & \\
\hline Column DMS & 0.12 & & 5.09 & & 90.37 & \\
\hline Row DMS & 0.08 & & 3.33 & & 59.07 & \\
\hline CV $(\%)$ & 4.95 & & 14.19 & & 114.44 & \\
\hline $\mathrm{Fc}$ & 1.75 & & 0.41 & & 1.06 & \\
\hline $\operatorname{Pr}>\mathrm{Fc}$ & 0.13 & & 0.87 & & 0.40 & \\
\hline \multicolumn{7}{|l|}{$0.20-0.30 \mathrm{~m}$ layer } \\
\hline Black oat & 1.09 & 1.06 & 16.35 & 19.6 & $13.14 \mathrm{~B}$ & $138.28 \mathrm{Aa}$ \\
\hline Black oat + radish & 1.07 & 1.13 & 15.42 & 16.63 & $24.06 \mathrm{~B}$ & 93.24 Aab \\
\hline Black oat + lupin bean & 1.03 & 1.11 & 18.58 & 14.92 & $73.52 \mathrm{~A}$ & 49.63 Aab \\
\hline Black oat + pea & 1.07 & 1.06 & 14.99 & 15.54 & $9.27 \mathrm{~A}$ & $72.48 \mathrm{Aab}$ \\
\hline Crotalaria juncea & 1.09 & 1.14 & 16.35 & 17.78 & $25.73 \mathrm{~A}$ & $16.75 \mathrm{Ba}$ \\
\hline Pigeon pea & 1.06 & 1.13 & 16.02 & 17.14 & $50.25 \mathrm{~A}$ & $9.49 \mathrm{Ab}$ \\
\hline Crotalaria spectabilis & 1.07 & 1.09 & 17.92 & 19.42 & $24.40 \mathrm{~A}$ & $30.75 \mathrm{Ab}$ \\
\hline Mean & 1.08 & & 16.91 & & 45.06 & \\
\hline Column DMS & 0.12 & & 5.71 & & 98.99 & \\
\hline Row DMS & 0.08 & & 3.73 & & 64.7 & \\
\hline CV $(\%)$ & 5.31 & & 15.55 & & 101.05 & \\
\hline $\mathrm{Fc}$ & 1.12 & & 1.31 & & 3.47 & \\
\hline $\operatorname{Pr}>\mathrm{Fc}$ & 0.36 & & 0.27 & & 0.01 & \\
\hline
\end{tabular}

Note. Means of treatments followed by uppercase letters in the row and lowercase letters in the column do not differ significantly from each other. Absence of lowercase letters in the column indicates that there was no significant difference. 


\subsubsection{Soil Density}

The density is an important physical attribute of the soil that influences root development, water infiltration, and is widely used in the evaluation of the state of soil compaction. In areas managed under no-till system (SPD), the highest values are found in the $0.10-0.20 \mathrm{~m}$ layer, due to the external pressure exerted by agricultural machines and implements (seed drills), resulting in the reduction of water flow and gas exchange in its lower layers, thus affecting crop productivity (Lal \& Shukla, 2004).

In accordance with the results presented in Table 1, Ds in the 0.0-0.10 $\mathrm{m}$ and $0.20-0.30 \mathrm{~m}$ layers did not differ significantly between treatments and periods. As for the 0.10-0.20 layer, there was a significant difference between the periods, of soil density and the saturated hydraulic conductivity.

The calculated values of coefficient of variation were $C V=7.85 \%(0.0-0.10 \mathrm{~m}$ layer $), \mathrm{CV}=4.95 \%(0.10-0.20 \mathrm{~m}$ layer) and $\mathrm{CV}=5.31 \%(0.20-0.30 \mathrm{~m}$ layer $)$ are values that can be considered homogeneous.

It can be noted that in the of $0.0-0.10 \mathrm{~m}$ and $0.10-0.20 \mathrm{~m}$ layers, all treatments obtained similar results for Ds, which shows that the species used in the two growing periods did not provide significant effects due to the good structural state of the soil (Bertol et al., 2004).

Cunha et al. (2011) evaluated the effect of different vegetation covers on soil physical attributes and did not find differences in soil Ds after one year of cultivation with cold season cover plants in a red Latosol. However, Lanzanova et al. (2016), during the period of higher evaluation, observed differences with higher values of Ds in systems that include cover plants, mainly hot season plants.

Lower density values in the upper layers were observed by Genro Junior et al. (2004), in typical clayey dystroferric red Latosol. The lower densities might have been related to the higher root density of the crops used and the higher $\mathrm{OM}$ content.

It can be noted that in the $0.10-0.20 \mathrm{~m}$ layer, it was found that in soils planted with Crotalaria juncea and pigeon pea there were significant differences in Ds over the periods considered. Ds rates above $1.30-1.40 \mathrm{Mg} \mathrm{m}^{-3}$ for soils with more than 55\% clay are considered critical (Reichert et al., 2003). In fact, Reinert and Reichert (2001) considered soil density values above $1.45 \mathrm{Mg} \mathrm{m}^{-3}$ as critical regardless of the content of clay.

Soils with Ds values considered critical restrict the growth and development of the root system, infiltration and transport of water, and gas exchange (Fonseca et al., 2007).

\subsubsection{Macroporosity}

Macropores are the results of the arrangement of aggregates, mesofauna and root action, and soil expansion and contraction, playing a key role in the movement of gases in the soil and the flow of water: infiltration, drainage, and solute transport (Embrapa, 2013).

Statistical analyses not showed differences between soil cover crops regarding the macroporosity at $0.0-0.10 \mathrm{~m}$ depth, where the association black oat + radish differed significantly from the rest during the 2016's campaign, but not the following year where all the covers crops were comparable (Table 1).

In this study, it was observed that macroporosity values were more than $10 \%$ for all soil cover species, which is considered adequate according to Seidel et al. (2015) as lower values would not secure respiratory demand of the roots, plant growth, activity of microorganisms in the drainage and aeration of the soil and the absorption of water and nutrients. In fact, the particularity of the soil macroporosity is to allow aeration and gravitational water and gas diffusion. The effects of the different cover plants on the macroporosity can be attributed to the different forms of their root systems; fasciculate in Poaceae and pivotal in Fabaceae for example.

The largest macroporosity $(19.60 \%)$ was found in the soil planted with Crotalaria spectabili, a speciess characterized by a pivotal root system. In fact, Fidalski and Tormena (2007) mentioned that a pivotal root system promoted a higher volume of macropores. The authors justifed this result by root decomposition and higher volume of micropores in Poaceae due to the production of very fine roots.

\subsubsection{Hydraulic Conductivity of Saturated Soil (Ksat)}

The Ksat is nothing more than the ability of the soil to conduct water from the upper layer to the deeper layers. In general, it is high in the first layers, decreasing in depth, and is influenced by Ds, macro, and micro. Ksat in all studied layers differed significantly (Table 1).

The coefficients of variation obtained were high i.e. $115.29 \%$ for $0.0-0.10 \mathrm{~m}$ layer, $114.44 \%$ for $0.10-0.20 \mathrm{~m}$ layer, and $101.05 \%$ for $0.20-0.30 \mathrm{~m}$ layer. The high variation was probably due to variation in soil porosity 
derived from structural variation of the soil. Gianello and Bueno (2015) stated that CV greater than 65\% indicates high heterogeneity of this variable (Ksat) in the area.

Pereira et al. (2008) stated that Ksat behaves differently in each horizon of the soil profile, as in Table 1, where the $0.20-0.30 \mathrm{~m}$ layer had a higher conductivity up to the most superficial layer for most treatments. This higher Ksat value is associated with the higher volume of macropores in this layer.

Aimrun et al. (2004), in their studies, mentioned an increase of the Ksat associated to an increase of the macro of the soil. Root decomposition produced continuous and more stable macropores, which favored water infiltration and gas exchange and reduced runoff. High-density, deep-rooted species that have the ability to break up compacted layers are preferable to form biopores, which are responsible of increasing Ksat (Yu et al., 2016).

\subsubsection{Soybean Yields}

The results of the analysis for soybean yield for the different treatments are shown in Table 2.

Table 2. Soybean grain yield in the 2016 and 2017 cycles in treatments involving cover species

\begin{tabular}{lll}
\hline \multirow{2}{*}{ Treatments } & \multicolumn{2}{c}{ Soybean grain yield $\left(\mathrm{kg} \mathrm{ha}^{-1}\right)$} \\
\cline { 2 - 3 } & 2016 & 2017 \\
\hline Black oat & $1938.60 \mathrm{~B}$ & $3296.30 \mathrm{~A}$ \\
Black oat + radish & $1735.72 \mathrm{~B}$ & $3097.29 \mathrm{~A}$ \\
Black oat + lupin bean & $1780.69 \mathrm{~B}$ & $3565.21 \mathrm{~A}$ \\
Black oat + pea & $1617.41 \mathrm{~B}$ & $3685.09 \mathrm{~A}$ \\
Crotalaria juncea & $2440.91 \mathrm{~A}$ & $2896.95 \mathrm{~A}$ \\
Pigeon pea & $2065.23 \mathrm{~B}$ & $3483.56 \mathrm{~A}$ \\
Crotalaria spectabilis & $1789.23 \mathrm{~B}$ & $3462.67 \mathrm{~A}$ \\
\hdashline Mean & 2623.73 & \\
Column DMS & 1196.1 & \\
Row DMS & 1960.15 & \\
CV (\%) & 32.33 & \\
Fc & 0.53 & \\
Pr $>$ Fc & 0.84 & \\
\hline
\end{tabular}

Note. Means followed by same uppercase letter in the row and same lowercase letters in the column do not differ significantly at $5 \%$ probability. Absence of lowercase letters in the column indicates that there was no significant difference.

Crop yield is a function of several factors, such as physical, chemical and biological properties of the soil, besides the climatic factor. During the initial stage, the soybean crop obtained a rainfall of $264.3 \mathrm{~mm}$, according to Figure 1, for the 2016-2017 cycle.

The precipitation in all months of the vegetative and reproductive cycle of the soybean at the IAPAR experimental station was approximately $1.118 \mathrm{~mm}$ in the period 2015-2016 and $970 \mathrm{~mm}$ in the period 2016-2017.

According to Albrecht et al. (2009), and Farias et al. (2015), for a good development and productivity, soybean requires $500-700 \mathrm{~mm}$ of precipitation during its cycle. Rainfall for the reproductive stage was sufficient or enough presenting $1.118 \mathrm{~mm}$ and 970 for the periods studied of crop.

During the stage of reproductive development of soybeans starting at flowering (stage R1) to grain filling (stage R5), the distribution of rain during the cycle contributed to the storage and availability of water in the soil, thus contributing to good uniformity of water and, subsequently, an increase in productivity (Figure 1).

The soybean productivity difference between 2016 and 2017 was due to intense attack of the Asian rust that reduced grain yield in 2016 .

Grain yield per soil did not differ significantly with the cover species, good initial structural conditions of the soil irrespective of the cover species, along with the good climatic conditions during the two soybean campaigns.

Figure 2 shows the multiple linear correlation of soybean yield as a function of Ds vs. Macro and Macro vs.

Ksat. 
Figure 2(A) shows that a significant increase in Ds (in the scale ranging from 1.0 to $1.17 \mathrm{Mg} \mathrm{m}^{-3}$, respectively representing the minimum and maximum values found in this experiment) and a reduction of the macro cause a higher grain yield. Due to the close relationship with other attributes, the great majority of the research converges to the fact that, with increasing density, there is a decrease in total porosity, macro and ksat, ionic absorption, and the subsequent increase in micro and resistance to soil penetration (Rosa Filho et al., 2009). Figure 2(B), a reduction of macro and Ksat contributed to an increase in grain yield.
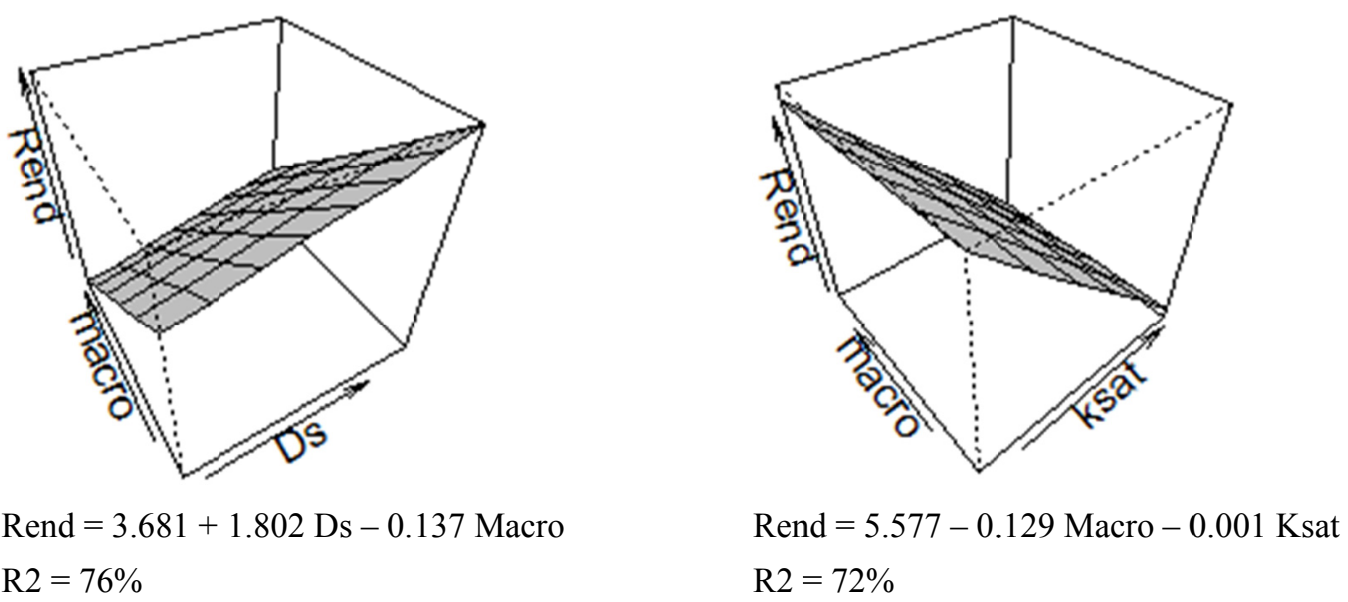

Figure 2. Multiple linear correlation of soybean yield as a function of Ds vs. Macro (A) and Macro vs. Ksat (B)

\section{Conclusions}

The vegetation cover species did not provide a significant improvement in the soil structural status. The soybean grain yield was positively influenced by the Ds when it ranged from 1.0 to $1.17 \mathrm{Mg} \mathrm{m}^{-3}$.

\section{References}

Aimrun, W., Amim, M. S. M., \& Eltaib, S. M. (2004). Effective porosity of paddy soils as an estimation of its saturated hydraulic conductivity. Geoderma, 121(3-4), 197-203. https://doi.org/10.1016/j.geoderma.2003. 11.010

Albrecht, L. P., Braccini, A. L., Marizangela, R. A., Scapim, C. A., \& Barbosa, M. C. (2009). Soybeans produced at the time of safrinha in the western region of the State of Paraná. Acta Scientiarum Agronomy, 31(1), 121-127.

Bertol, I., Albuquerque, J. A., Leite, D., Amaral, A. J., \& Zoldan Jr., W. A. (2004). Physical properties of the soil under conventional tillage and direct seeding in crop rotation and succession, compared to the native field. Revista Brasileira de Ciencia do Solo, 28, 155-163. https://doi.org/10.1590/S0100-06832004000100015

Camargo, A. P. de, Marin, F. R., Sentelhas, P. C., \& Picini, A. G. (1999). Adjustment of the Thornthwaite equation to estimate potential evapotranspiration in arid and superhumid climates, based on the daily thermal amplitude. Revista Brasileira de Agrometeorologia, 7(2), 251-257.

Cunha, E. de Q., Stone, L. F., Ferreira, E. P. de B., Didonet, A. F., Moreira, A. A., \& Leandro, W. M. (2011). Soil tillage systems and cover crops in the organic production of beans and corn. I-physical attributes of the soil. Revista Brasileira de Ciência do Solo, 35(2), 589-602. https://doi.org/10.1590/S0100-06832011000200028

Doneda, A. (2010). Soil intercropping and intercropping plants: Decomposition and nitrogen supply to maize. Santa Maria, RS, Brasil.

Embrapa (Empresa Brasileira de Pesquisa Agropecuária). (1997). Manual of soil analysis methods. Embrapa Solos (2nd ed., p. 212). National Soil Research Center, Rio de Janeiro, Brazil.

Embrapa (Empresa Brasileira de Pesquisa Agropecuária). (2013). Manual of soil analysis methods. Sistema brasileiro de classificação de solos (3rd ed.). National Soil Research Center, Brasília, Brazil.

Farias, J. R. B., Neumaier, N., \& Nepomuceno, A. L. (2015). Climatic requirements. Empresa Breasileira de Pesquisa Agropecuaria-SECA: Soybean in water shortages. Londrina: Embrapa Soja. 
Ferreira, D. F. (2011). Sisvar: A computer statistical analysis system. Ciência e Agrotecnologia, 35, $1039-1042$. https://doi.org/10.1590/S1413-70542011000600001

Fidalski, J., \& Tormena, C. A. (2007). Homogeneity of the physical quality of the soil between the lines of an orange orchard with permanent vegetation management systems. Revista Brasileira de Ciência do Solo, 31(4), 637-645. https://doi.org/10.1590/S0100-06832007000400004

Fonseca, G. C., Carneiro, M. A. C., Costa, A. R., Oliveira, G. C., \& Balbino, L. C. (2007). Physical, chemical and biological attributes of Cerrado Dystroferric Red Latosol under two crop rotations. Revista Agropecuária Tropical, 37(1), 22-30.

Genro Junior, S. A., Reinert, D. J., \& Reichert, J. M. (2004). Temporal variability of the resistance to penetration of a clayey Oxisol under direct seeding with crop rotation . Revista Brasileira de Ciência do Solo, 28, 477-484.

Gianello, E. M., \& Bueno, C. R. P. (2015). Spatial variability of attributes and soil loss in the definition of management zones. Pesquisa Agropecuária Tropical, 45(1), 18-28.

IAPAR (Instituto Agronomico do Paraná). (2000). Climatic map of Estado do Paraná. Londrina

Lal, R., \& Shukla, M. K. (2004). Principles of soil physics. Ohio, USA: The Ohio University Columbus.

Lanzanova, M. E., Nicoloso, R. S., Lovato, T., Eltz, F. L. F., Amado, T. J. C., \& Reinert, D. J. (2016). Residual effect of soil tillage on water erpsion from a tupic Paleudalf under long-term no-tillage and cropping systems. Revista Brasileira de Ciência do Solo, 34, 1333-1342. https://doi.org/10.1590/S0100-0683201000 0400030

Pereira, T. I., Uhde, L. T., Gubiani, P. I., Reichert, L. M. D. J., \& Vogelmann, E. S. (2008). Saturated Hydraulic Conductivity and soil physical properties in degraded pasture area in Argissolo in Central Depression of RS. Grupo de física do solo da UFSM.

R Core Team. (2016). A language and environment for statistical computing. R Foundation for Statistical Computing, Vienna, Austria. Retrieved from https://www.Rproject.org

Reichert, J. M., Albuquerque, J. A., Gubiani, P. I., Kaiser, D. R., Minella, J. P. G., \& Reinert, D. J. (2011). Soil hydrology, plant water availability and agroclimatic zoning. Sociedade Brasileira de Ciência do Solo, 2, $1-54$.

Reichert, J. M., Reinert, D. J., \& Braida, J. A. (2003). Soil quality and sustainability of agricultural systems. Ciência Ambiental, 27, 29-48.

Reinert, D. J., \& Reichert, J. M. (2001). Soil physical properties in irrigated no-tillage system (pp. 114-131). Santa Maria, Brazil.

Reinert, D. J., \& Reichert, J. M. (2006). Physical properties of soil (p. 18). Universidade Federal de Santa Maria, Brazil.

Rosa Filho, G., Carvalho, M. P., Andreotti, M., Montanari, R., Binotti, F. F. S., \& Gioia, M. T. (2009). Variability of soybean yield as a function of the physical attributes of a dystroferric Red Latosol under no-tillage. Revista Brasileira de Ciência do Solo, 33(2), 283-293. https://doi.org/10.1590/S0100-06832009000200006

Santos, J. N., \& Pereira, E. D. (2013). Letter of susceptibility to water infiltration in the soil in the river sub-basin Maracanã-MA (p. 20). Cadernos de Pesquisa, São Luís.

Seidel, E. P., Mattia, V., Mattei, E., \& Corbari, F. (2015). Dry matter production and soil physical properties in corn and brachiaria consortium. Scientia Agraria Paranaensis, 14(1), 18-25. https://doi.org/10.18188/ 1983-1471/sap.v14n1p18-24

Serafim, M. E., Oliveira, G. C., Lima, J. M., Silva, B. M., Zeviani, W. M., \& Lima, V. M. P. (2013). Water availability and distinction of environments for coffee cultivation. Revista Brasileira de Engenharia Agrícola e Ambiental, 17(4), 362-370. https://doi.org/10.1590/S1415-43662013000400002

Stone, L. F., \& Silveira, P. M. (2001). Effects of cropping system and crop rotation on porosity and soil density. Revista Brasileira de Ciência do Solo, 25, 395-401. https://doi.org/10.1590/S0100-06832001000200015

Yu, Y., Loiskandl, W., Kaul, H., Himmelbauer, M., Wei, W., Chen, L., \& Bodner, G. (2016). Estimation of runoff mitigation by morphologically different cover crop root systems. J. Hydrol., 538, 667-676. https://doi.org/ 10.1016/j.jhydrol.2016.04.060 
Zhao, D., Xu, M., Liu, G., Yao, X., Tuo, D., Zhang, R., Xiao, T., \& Peng, G. (2016). Quantification of soil aggregate microstructure on abandoned cropland during vegetative succession using synchrotron radiation-based micro-computed tomography. Soil \& Tillage Research, 165, 239-246. https://doi.org/ 10.1016/j.still.2016.08.007

\section{Copyrights}

Copyright for this article is retained by the author (s), with first publication rights granted to the journal.

This is an open-access article distributed under the terms and conditions of the Creative Commons Attribution license (http://creativecommons.org/licenses/by/4.0/). 